\section{Case Report}

Check for updates

\title{
Goat's milk anaphylaxis in a cow's milk tolerant child
}

\section{Si Hui Goh $\mathbb{D}^{*}$, Kok Wee Chong, Wenyin Loh, and Anne Eng Neo Goh}

\section{OPEN ACCESS}

Received: Aug 4, 2019

Accepted: Oct 15, 2019

*Correspondence to

Si Hui Goh

Allergy Service, Department of Paediatric

Medicine, KK Women's and Children's

Hospital, 100 Bukit Timah Road,

Singapore 229899, Singapore.

Tel: +65-63941127

E-mail: goh.si.hui@singhealth.com.sg

Copyright (c) 2019. Asia Pacific Association of Allergy, Asthma and Clinical Immunology. This is an Open Access article distributed under the terms of the Creative Commons Attribution Non-Commercial License (https:// creativecommons.org/licenses/by-nc/4.0/) which permits unrestricted non-commercial use, distribution, and reproduction in any medium, provided the original work is properly cited.

ORCID iDs

Si Hui Goh iD

https://orcid.org/0000-0001-5028-6404

Conflict of Interest

The authors have no financial conflicts of interest.

Author Contributions

Conceptualization: Si Hui Goh, Kok Wee Chong. Data curation: Si Hui Goh, Kok Wee Chong. Formal analysis: Si Hui Goh. Funding acquisition: Si Hui Goh. Investigation: Si Hui Goh. Project administration: Si Hui Goh. Resources: Si Hui Goh. Supervision: Wenyin Loh, Anne Eng Neo Goh. Validation: Si Hui Goh. Writing - original draft: Si Hui Goh, Kok Wee Chong. Writing - review \& editing: Wenyin Loh, Anne Eng Neo Goh.
Allergy Service, Department of Paediatric Medicine, KK Women's and Children's Hospital, Singapore

\section{ABSTRACT}

Goat's milk (GM) allergy commonly occurs together with cow's milk (CM) allergy due to cross-reactivity between highly homologous proteins. We present an unusual case of GM anaphylaxis in a CM tolerant child.

Keywords: Anaphylaxis; Food hypersensitivity; Milk hypersensitivity; Child

\section{INTRODUCTION}

Cow's milk (CM) allergy is among the most common childhood food allergy in developing and developed countries [1, 2]. Goat's milk (GM) allergy commonly occurs in patients with CM allergy due to clinical cross-reactivity from highly homologous GM and CM proteins [3]. It is unusual to have patients with isolated GM allergy without CM allergy. The literature on GM allergy in CM tolerant patients is limited to case reports [4, 5] and case series [6, 7] originating from Europe. We present a unique case of an Asian child who is tolerant of CM but experienced GM anaphylaxis. The patient's parent gave written informed consent for publication of data.

\section{CASE REPORT}

Patient $\mathrm{H}$ is a 7-year-old Chinese boy with a background of eczema, allergic rhinitis, and shellfish allergy. He is clinically tolerant of CM and consumes it daily.

He first encountered GM at 6 years of age. The patient developed anaphylaxis 30 minutes after ingestion of GM powder sweets. He experienced urticaria, cough, and wheeze requiring treatment of oral antihistamines and nebulized bronchodilators by his family physician. He was not referred to an allergist.

At 7 years of age, he drank $70 \mathrm{~mL}$ of GM formula. Within 15 minutes, he developed anaphylaxis, with angioedema, voice hoarseness, breathlessness, vomiting, abdominal pain, and drowsiness. He visited the Emergency Department and was treated with one dose of intramuscular adrenaline. Serum tryptase was elevated at $14.6 \mu \mathrm{g} / \mathrm{L}, 2$ hours postreaction, compared to a baseline tryptase of $2.4 \mu \mathrm{g} / \mathrm{L}$. 
Skin prick test showed histamine $6 \mathrm{~mm}$, diluent $0 \mathrm{~mm}$, prick-to-prick GM formula $7.5 \mathrm{~mm}$, fresh GM $12 \mathrm{~mm}$. Specific IgE to CM $0.83 \mathrm{kU} / \mathrm{L}, \mathrm{GM} 54.8 \mathrm{kU} / \mathrm{L}$, and nBos d8 casein $1.51 \mathrm{kU} / \mathrm{L}$.

He holds an adrenaline auto-injector and has been advised dietary avoidance of GM and sheep milk (SM).

\section{DISCUSSION}

This is the first case report from Asia of GM anaphylaxis without CM allergy. CM, GM, and SM are greatly similar. In animal taxonomy, the Bovidae family of cloven-hoofed, ruminant mammals consists of subfamily bovinae (cow) and caprinae (goat and sheep). Bovidae milk consists of casein and whey, and casein itself comprises of $\alpha S_{1}, \alpha S_{2}, \beta, \kappa$, and $\gamma$ casein. Despite 85\%-90\% amino acid sequence homology between GM and CM caseins, some patients selectively react to GM without CM allergy [6].

In 1999, Umpiérrez et al. [4] first described a patient with allergy to goat and sheep cheese despite tolerance to CM. Goat casein was determined to be the main allergen via IgE enzyme linked immunosorbent assay and immunoblotting. In 2006, Ah-Leung et al. [6] described a case series of 28 children from France experiencing GM allergy without CM allergy.

There were multiple similarities between our patient and cases described in literature. Firstly, patients were older children, with a mean age of 6 years described in the French case series and the inclusion of 2 adults among the 5 patients described by Viñas et al. [7]. Secondly, the number of recurrent reactions prior to diagnosis. Similar to our patient, $71 \%$ of the French cohort experienced 2 or more reactions before diagnosis. Thirdly, the severity of reaction. Our patient experienced anaphylaxis, as with $57 \%$ of the French cohort. In the French case series, the authors highlighted that GM was a hidden allergen in pasta, moussaka, pizzas, candies, and sandwiches.

Using enzyme allergosorbent tests (EAST) and EAST inhibition studies with the sera of allergic children, researchers confirmed Umpiérrez's finding that casein was the main allergen and further isolated the allergenic proteins to $\alpha S_{1}, \alpha S_{2}, \beta$ casein. In Spain, Rodríguez et al. [8] highlighted the persistence of GM and SM allergy in $25.9 \%$ of patients who successfully completed CM-oral immunotherapy.

GM and SM milk consist of only 3.5\% of the world's milk [9]. It can be found in various forms including fresh pasteurized milk, milk powder formulated for infants and children, sweets, cheese, and yoghurt. In Asia, while China and India are major GM producers, GM farms and dairies are scattered in multiple countries including Singapore, Malaysia, Thailand, and Korea [10]. With global trade, GM products originating from Europe, New Zealand, and Australia are being exported to Asia. Our case report highlights a unique cause of food anaphylaxis that is relevant in Asia.

\section{REFERENCES}

1. Rona RJ, Keil T, Summers C, Gislason D, Zuidmeer L, Sodergren E, Sigurdardottir ST, Lindner T, Goldhahn K, Dahlstrom J, McBride D, Madsen C. The prevalence of food allergy: a meta-analysis. J Allergy Clin Immunol 2007;120:638-46.

PUBMED | CROSSREF 
2. Loh W, Tang MLK. The epidemiology of food allergy in the global context. Int J Environ Res Public Health 2018;15:pii: E2043. PUBMED | CROSSREF

3. Bellioni-Businco B, Paganelli R, Lucenti P, Giampietro PG, Perborn H, Businco L. Allergenicity of goat's milk in children with cow's milk allergy. J Allergy Clin Immunol 1999;103:1191-4.

PUBMED | CROSSREF

4. Umpiérrez A, Quirce S, Marañón F, Cuesta J, García-Villamuza Y, Lahoz C, Sastre J. Allergy to goat and sheep cheese with good tolerance to cow cheese. Clin Exp Allergy 1999;29:1064-8. PUBMED | CROSSREF

5. Muñoz Martín T, de la Hoz Caballer B, Marañón Lizana F, González Mendiola R, Prieto Montaño P, Sánchez Cano M. Selective allergy to sheep's and goat's milk proteins. Allergol Immunopathol (Madr) 2004;32:39-42. PUBMED

6. Ah-Leung S, Bernard H, Bidat E, Paty E, Rancé F, Scheinmann P, Wal JM. Allergy to goat and sheep milk without allergy to cow's milk. Allergy 2006;61:1358-65. PUBMED | CROSSREF

7. Viñas M, Carnés J, López-Matas MA, Hernández N, Castillo MJ, Ibero M. Allergy to goat and sheep cheese with tolerance to cow's milk and its derivatives. Allergol Immunopathol (Madr) 2014;42:186-90. PUBMED | CROSSREF

8. Rodríguez del Río P, Sánchez-García S, Escudero C, Pastor-Vargas C, Sánchez Hernández JJ, Pérez-Rangel I, Ibáñez MD. Allergy to goat's and sheep's milk in a population of cow's milk-allergic children treated with oral immunotherapy. Pediatr Allergy Immunol 2012;23:128-32. PUBMED | CROSSREF

9. Pulina G, Milán MJ, Lavín MP, Theodoridis A, Morin E, Capote J, Thomas DL, Francesconi AHD, Caja G. Invited review: Current production trends, farm structures, and economics of the dairy sheep and goat sectors. J Dairy Sci 2018;101:6715-29. PUBMED | CROSSREF

10. Escareño L, Salinas-Gonzalez H, Wurzinger M, Iñiguez L, Sölkner J, Meza-Herrera C. Dairy goat production systems: status quo, perspectives and challenges. Trop Anim Health Prod 2013;45:17-34. PUBMED | CROSSREF 